\title{
Pinoresinol Diglucoside Alleviates oxLDL-Induced Dysfunction in Human Umbilical Vein Endothelial Cells
}

\author{
Jinpeng Yao, ${ }^{1,2}$ Zhipeng Zou, ${ }^{2}$ Xiangfen Wang, ${ }^{3}$ Xiaoping Ji, ${ }^{1}$ and Jun Yang ${ }^{4}$ \\ ${ }^{1}$ Department of Cardiology, Qilu Hospital of Shandong University, Jinan, Shandong 250012, China \\ ${ }^{2}$ Department of Cardiology, Yantai Yeda Hospital of Binzhou Medical University, Yantai, Shandong 264100, China \\ ${ }^{3}$ Department of Geriatrics, Yantai Yeda Hospital of Binzhou Medical University, Yantai, Shandong 264100, China \\ ${ }^{4}$ Yantai Yuhuangding Hospital of Qingdao University, Yantai, Shandong 264000, China \\ Correspondence should be addressed to Jun Yang; yangjqh@126.com
}

Received 18 July 2016; Revised 11 October 2016; Accepted 19 October 2016

Academic Editor: Yong C. Boo

Copyright ( 2016 Jinpeng Yao et al. This is an open access article distributed under the Creative Commons Attribution License, which permits unrestricted use, distribution, and reproduction in any medium, provided the original work is properly cited.

\begin{abstract}
Atherosclerotic cardiovascular diseases are the leading causes of morbidity and mortality worldwide. Deposition of oxidized lowdensity lipoprotein (oxLDL) is one of the initiators and promoters of atherosclerosis. Eucommia lignans were shown to possess antihypertensive effects. This study aimed to investigate the effects of pinoresinol diglucoside (PD), a Eucommia lignan, on oxLDLinduced endothelial dysfunction. HUVECs were treated with oxLDL and/or PD followed by assessing radical oxygen species (ROS), apoptosis, nitrogen oxide (NO), malondialdehyde (MDA), and superoxide dismutase (SOD) activity with specific assays kits, mRNA levels with quantitative real-time polymerase chain reaction (PCR), and protein levels with western blot. PD abolished oxLDLinduced ROS and MDA production, apoptosis, upregulation of lectin-like oxidized LDL recptor-1 (LOX-1), intercellular Adhesion Molecule 1 (ICAM-1), and nuclear factor kappa-light-chain-enhancer of activated B-cells (NF- $\kappa$ B), and activation of p38MAPK (mitogen-activated protein kinases)/NF- $\kappa$ B signaling. Meanwhile, PD alleviated oxLDL-caused inhibition of SOD activity, eNOS expression, and NO production. These data demonstrated that PD was effective in protecting endothelial cells from oxLDL-caused injuries, which guarantees further investigation on the clinical benefits of PD on cardiovascular diseases.
\end{abstract}

\section{Introduction}

Cardiovascular diseases (CVDs) are the leading causes of death and burden of disease worldwide $[1,2]$. As the underlying cause of most CVDs including stroke and myocardial infarction, atherosclerosis is considered as a chronic inflammatory disease which is initiated by endothelial injuries and progressed with the deposition of oxidized low-density lipoprotein (oxLDL) and inflammatory cells (monocytes, macrophages, etc.) to the arterial wall [3-5]. Though many pathways are involved in the development of atherosclerosis, oxLDL plays a critical role throughout the process by promoting the recruitment of inflammatory cells, increasing endothelium injuries, stimulating the proliferation of vascular smooth muscle cells, and promoting the production and release of inflammatory mediators including radical oxygen species (ROS) and cytokine [3-6]. Besides, oxLDL promotes monocyte adhesion to endothelial cells through ROS and NF- $\kappa$ B activation [6-8].

OxLDL-induced oxidative stress and ROS production play a critical role in endothelial injury and [9]. OxLDL could stimulate NADPH oxidase production of ROS by activating AMPK/PKC pathway [10] or increasing mitochondrial ROS generation [11]. The chronic high level ROS causes inflammation and endothelial injury, which are the deciding processes for the initiation and progression of atherosclerosis.

Pinoresinol diglucoside (PD) is one of the major lignans isolated from Eucommia ulmoides Oliver bark which is called Duzhong in Traditional Chinese medicine. Lignans, iridoids, flavonoids, polysaccharides, terpenes, and proteins have been identified from Eucommia bark [12]. Eucommia extract was shown to possess antioxidative effect [12, 13], hypoglycemic and hypolipidemic effects [14, 15], and antihypertensive effect $[16,17]$. Lignans, the major bioactive compounds of 
Eucommia, was shown to inhibit hypertensive renal injury [18] and angiotensin II induced proliferation [19, 20] and extracellular matrix production [20] in rat mesangial cells. This study aimed to investigate whether PD has protective effects against oxLDL-induced endothelial dysfunction.

\section{Methods}

2.1. Cell Culture. Human umbilical vein endothelia cells (HUVECs) were purchased from ATCC (Manassas, VA) and maintained in DMEM (SH30022.01B, Hyclone, Logan, UT) supplemented with 10\% fetal bovine serum (16000-044, Life Technologies, Shanghai, China), $0.1 \mathrm{mg} / \mathrm{mL}$ heparin (Life Technologies), $50 \mu \mathrm{g} / \mathrm{mL}$ endothelial cell growth supplement (E2759, Sigma, St. Louis, MO), and $100 \mathrm{U} / \mathrm{mL}$ penicillin and $100 \mu \mathrm{g} / \mathrm{mL}$ streptomycin (Hyclone) in a humidified incubator with $5 \% \mathrm{CO}_{2}$ at $37^{\circ} \mathrm{C}$.

2.2. LDL Isolation and Oxidation. All protocols were approved by the institute review committee of Shandong University. A written informed consent form was obtained from each healthy blood donor. LDL was isolated from plasma of healthy individuals and oxidized according to previously described methods [21-23]. Briefly, native LDL was isolated by sequential ultracentrifugation $(1.019<d<1.063 \mathrm{~g} / \mathrm{mL})$ of plasma in the presence of EDTA and dialyzed against 500 volumes of PBS for $48 \mathrm{~h}$ at $4^{\circ} \mathrm{C}$ to remove the EDTA. LDL was oxidized by incubating LDL in $0.5 \mathrm{mg} / \mathrm{mL}$ protein with $5 \mu \mathrm{mol} / \mathrm{L} \mathrm{CuSO}_{4}$ for $18 \mathrm{~h}$. The amount of thiobarbituric acid reactive substances was monitored using a TBARS assay kit (10009055, Cayman Chemical, Ann Arbor, MA) according to manufacturer's instructions and the values of malondialdehyde (MDA) equivalents increased from $0.93 \pm 0.16 \mathrm{nmol} / \mathrm{mg}$ protein of native LDL to $21.7 \pm 2.3 \mathrm{nmol} / \mathrm{mg}$ protein of $\mathrm{CuSO}_{4}$-treated LDL. Then, oxLDL samples were dialyzed against 500 volumes of PBS at $4^{\circ} \mathrm{C}$ for $48 \mathrm{~h}$ to remove the $\mathrm{Cu}^{2+}$ and were filtered through a $0.45 \mu \mathrm{m}$ filter. The protein concentrations of native LDL and oxLDL were measured with a Pierce ${ }^{\mathrm{TM}}$ Coomassie Plus (Bradford) Assay Kit (23236, ThermoFisher, Grand Island, NY).

2.3. Pinoresinol Diglucoside (PD). PD was purchased from Qingdao Jie Shi Kang Biotechnology (Qingdao, China), which had a purity $\geq 99 \%$. PD was purified from Eucommia ulmoides Oliver bark. The CAS number of PD is 63902-385 , and molecular formula is $\mathrm{C}_{32} \mathrm{H}_{42} \mathrm{O}_{16}$ with a molecular weight of $682.668 \mathrm{~g} / \mathrm{mol}$. PD stock solution was $10 \mathrm{mmol} / \mathrm{L}$ in methanol and working solution was diluted with culture medium.

2.4. Apoptosis Assay. HUVECs were seeded into 6-well plates $\left(2 \times 10^{5} /\right.$ well $)$ and cultured for $24 \mathrm{hrs}$ before experimental treatments. The cells were pretreated with 0.1 or $1 \mu \mathrm{mol} / \mathrm{L}$ of pinoresinol diglucoside (PD) for $60 \mathrm{~min}$ where indicated before being treated with or without $100 \mu \mathrm{g} / \mathrm{mL}$ of oxLDL for $24 \mathrm{hrs}$. The cells were then collected and stained using FITC Annexin V Apoptosis Detection Kit with PI (640914,
Biolegend, San Diego, CA) according to the manufacturer's protocol. Briefly, the cells were washed twice with cold BioLegend's Cell Staining Buffer and resuspended in Annexin $\mathrm{V}$ Binding Buffer at a concentration of $0.5-1.0 \times 10^{7}$ cells $/ \mathrm{mL}$. Then, $100 \mu \mathrm{L}$ of cell suspension was transferred into a $5 \mathrm{~mL}$ test tube, mixed with $5 \mu \mathrm{L}$ of FITC Annexin $\mathrm{V}$ and $10 \mu \mathrm{L}$ of Propidium Iodide Solution, and incubated at room temperature in the dark for $15 \mathrm{~min}$ with gentle vortexing. $400 \mu \mathrm{L}$ of Annexin V Binding Buffer was added to each tube before being analyzed on a BD Accuri ${ }^{\mathrm{TM}}$ C6 (BD Biosciences, Shanghai, China).

2.5. ROS Assessment. The levels of intracellular ROS were analyzed using OxiSelect ${ }^{\mathrm{TM}}$ Intracellular ROS Assay Kit (STA342, Cell Biolabs, San Diego, CA) after HUVECs were treated with $100 \mu \mathrm{g} / \mathrm{mL}$ of oxLDL and/or $1 \mu \mathrm{mol} / \mathrm{L}$ of PD ( 60 min prior to adding oxLDL) for $24 \mathrm{hrs}$. Briefly, the cells were washed 3 times with DPBS after oxLDL/PD treatment and $200 \mu \mathrm{L}$ of $1 \mathrm{x}$ DCFH-DA $\left(2^{\prime}, 7^{\prime}\right.$-dichlorodihydrofluorescin diacetate) media solution was added to the cells, which was incubated at $37^{\circ} \mathrm{C}$ for $30 \mathrm{~min}$ always in light. The cells were then washed 3 times with DPBS and analyzed on a BD Accuri C6 or photographed on an Olympus IX70 Inverted Microscope (Olympus, Shanghai China).

2.6. Measurement of NO. The intracellular NO content was assessed with Total Nitric Oxide Assay Kit (S0023, Beyotime, Shanghai, China) following manufacturer's instructions. After 24 hrs treatment with oxLDL and/or PD, the HUVECs were lyzed with Cell and Tissue Lysis Buffer for Nitric Oxide Assay (S3090, Beyotime) and centrifuged at $14000 \times \mathrm{g}$ at $4^{\circ} \mathrm{C}$ for $10 \mathrm{~min} .60 \mu \mathrm{L}$ of supernatant was transferred into 96 -well assay plate, mixed with $5 \mu \mathrm{L}$ of NADPH $(2 \mathrm{mmol} / \mathrm{L}), 10 \mu \mathrm{L}$ of $\mathrm{FAD}$, and $5 \mu \mathrm{L}$ of nitrate reductase, and incubated $30 \mathrm{~min}$ at $37^{\circ} \mathrm{C}$. LDH Buffer and $\mathrm{LDH}(10 \mu \mathrm{L}$ each) were added into assay mixture followed by $30 \mathrm{~min}$ incubation at $37^{\circ} \mathrm{C}$. Then, $50 \mu \mathrm{L}$ of Griess Reagent I and $50 \mu \mathrm{L}$ Griess Reagent II were added and the reaction was continued at room temperature for $10 \mathrm{~min}$ before the absorbance was measured at $540 \mathrm{~nm}$ on a microplate reader (BioTek, Beijing, China).

2.7. Assessment of MDA Content. The MDA content was measured using a TBARS assay kit (10009055, Cayman Chemical) according to manufacturer's protocol. Briefly, HUVECs after oxLDL and/or PD treatment for 24 hrs were lyzed in PBST $\left(10^{6}\right.$ cells in $0.1 \mathrm{~mL}$ PBST) by sonication on ice. $100 \mu \mathrm{L}$ of cell lysate or standard was added to a $5 \mathrm{~mL}$ vial, which was mixed in $100 \mu \mathrm{L}$ of SDS solution and $4 \mathrm{~mL}$ of the color reagent. The vials were capped and boiled for $60 \mathrm{~min}$, incubated on ice for $10 \mathrm{~min}$, and centrifuged $10 \mathrm{~min}$ at $1600 \times \mathrm{g}$ at $4^{\circ} \mathrm{C} .150 \mu \mathrm{L}$ of supernatant was transferred into an assay plate and read on a FLx800 fluorescent reader (BioTek) with excitation $530 \mathrm{~nm}$ and emission $550 \mathrm{~nm}$.

2.8. Analysis of Cellular Total Superoxide Dismutase (SOD) Activity. The total SOD activity was measured using a Total Superoxide Dismutase Assay Kit with NBT (S0109, Beyotime) 

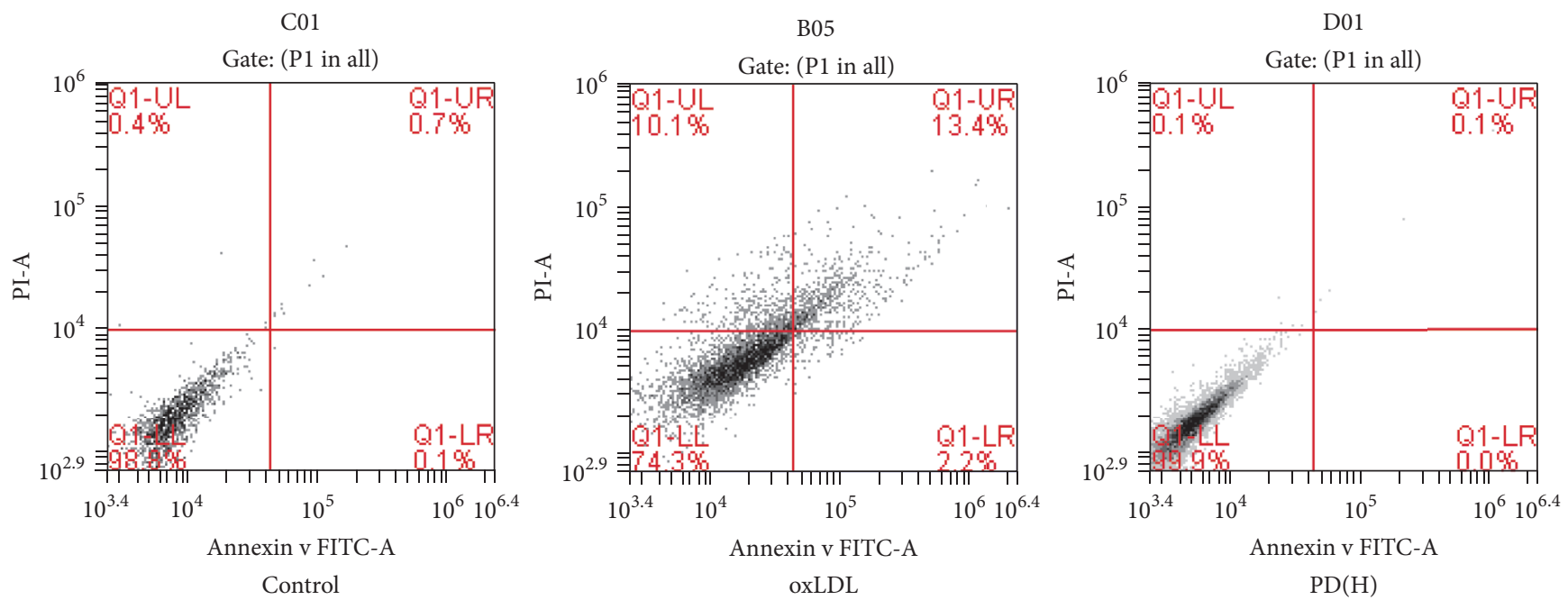

C04

$\mathrm{C} 02$
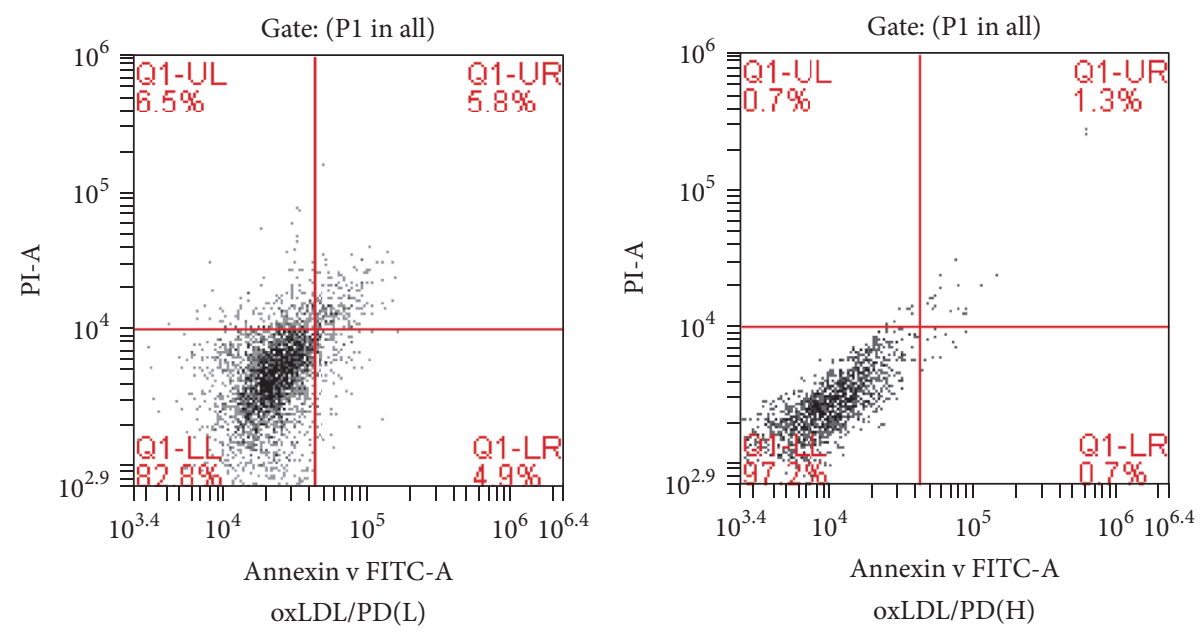

(a)

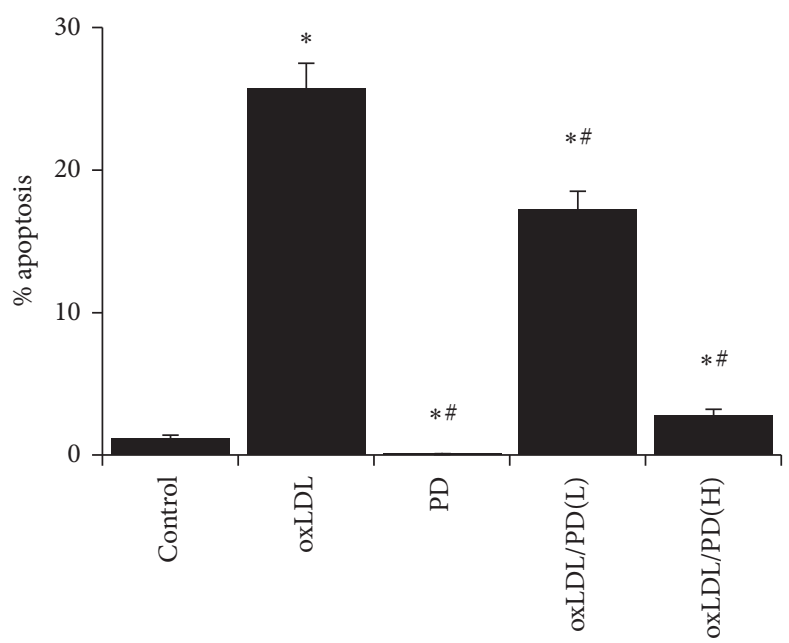

(b)

FIgURE 1: Pinoresinol diglucoside inhibits oxLDL-induced apoptosis. (a) The apoptosis of HUVECs was analyzed by Annexin V/PI staining followed by flow cytometry. HUVECs were cultured for $24 \mathrm{hrs}$ without treatment, with $100 \mu \mathrm{g} / \mathrm{mL}$ of oxLDL, $1 \mu \mathrm{mol} / \mathrm{L} \mathrm{of} \mathrm{PD,} 100 \mu \mathrm{g} / \mathrm{mL}$ of oxLDL plus $0.1 \mu \mathrm{mol} / \mathrm{L}$ of PD, and $100 \mu \mathrm{g} / \mathrm{mL}$ of oxLDL plus $1 \mu \mathrm{mol} / \mathrm{L}$ of PD. (b) Quantitative analysis of percentage of apoptotic cells of HUVECs with the different treatment listed in (a). Experiments were performed 3 independent times with 3 replications. ${ }^{*} p<0.05$ compared to control cells; ${ }^{\#} p<0.05$ compared to oxLDL-treated cells. 


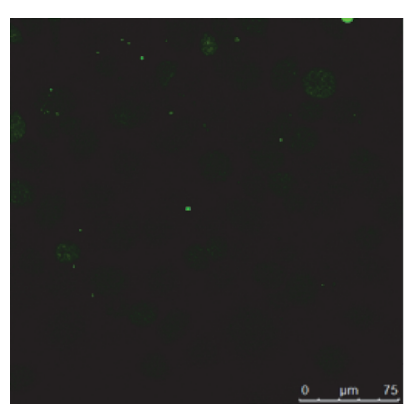

Control

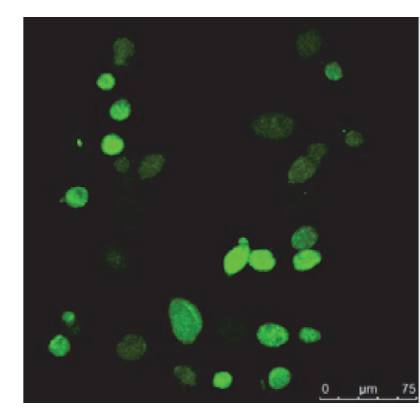

oxLDL

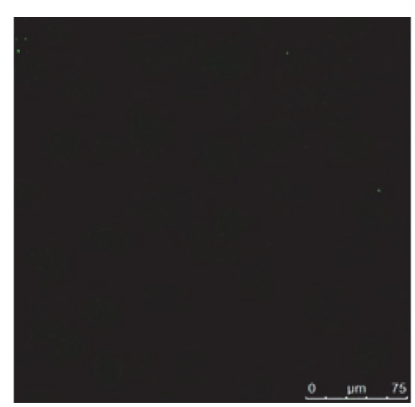

PD

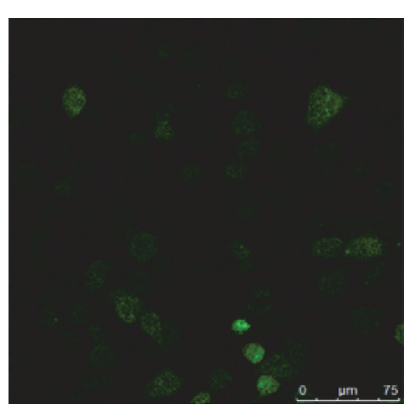

oxLDL/PD

(a)

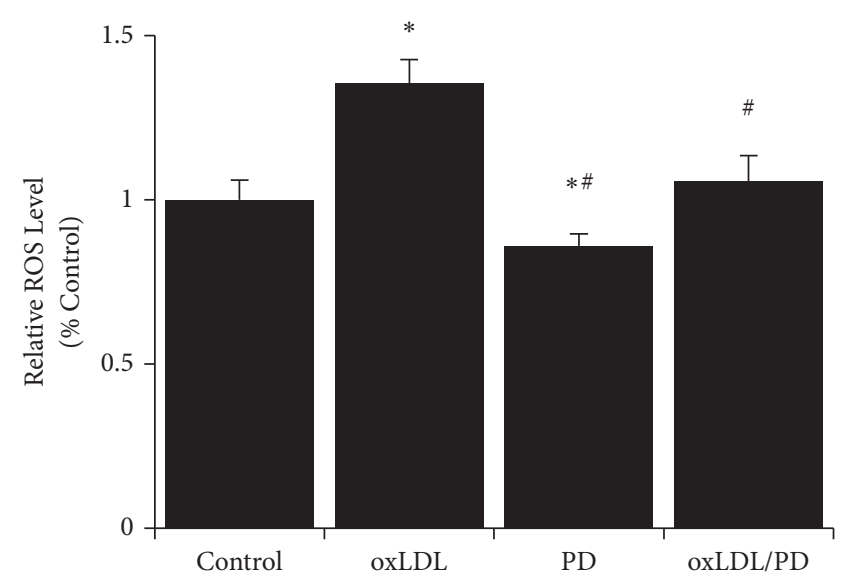

(b)

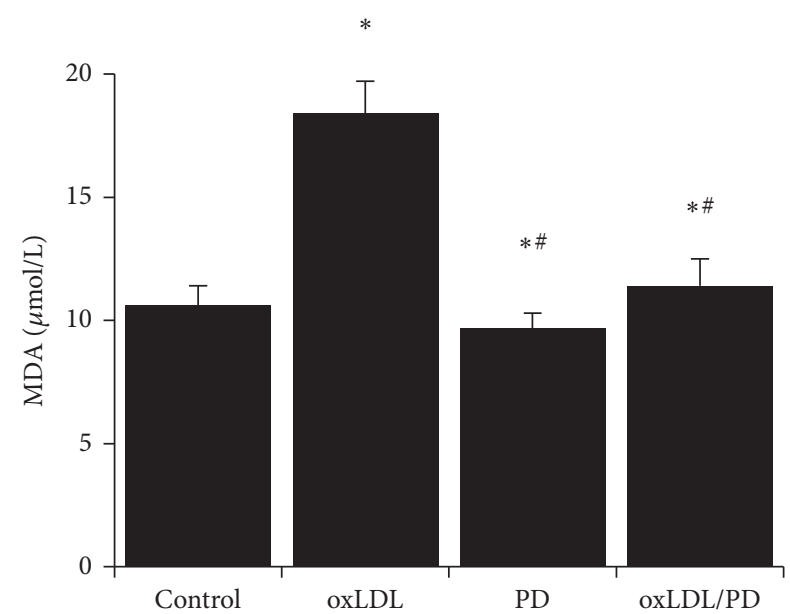

(c)

FIGURE 2: Pinoresinol diglucoside alleviates oxidative stress caused by oxLDL. (a) Representative pictures of HUVECs stained with DCFH-DA after being cultured without treatment, with $100 \mu \mathrm{g} / \mathrm{mL}$ of oxLDL, $1 \mu \mathrm{mol} / \mathrm{L}$ of PD, and $100 \mu \mathrm{g} / \mathrm{mL}$ of oxLDL plus $1 \mu \mathrm{mol} / \mathrm{L}$ of PD for $24 \mathrm{hrs}$. (b) The relative ROS levels of HUVECs were analyzed by flow cytometry following DCFH-DA staining after being cultured without treatment, with $40 \mu \mathrm{g} / \mathrm{mL}$ of oxLDL, $1 \mu \mathrm{mol} / \mathrm{L}$ of PD, and $40 \mu \mathrm{g} / \mathrm{mL}$ of oxLDL plus $1 \mu \mathrm{mol} / \mathrm{L}$ of PD for $24 \mathrm{hrs}$. (c) The lipid peroxidation was assessed by measuring the contents of malondialdehyde in HUVECs treated with oxLDL and/or PD. Experiments were performed 3 independent times with 3 replications. ${ }^{*} p<0.05$ compared to control cells; ${ }^{\#} p<0.05$ compared to oxLDL-treated cells.

following the manufacturer's protocol. After 24 hrs treatment with oxLDL and/or PD, HUVECs were washed twice with cold PBS, lyzed in PBS by pulse sonication on ice, and centrifuged at $13000 \times \mathrm{g}$ at $4^{\circ} \mathrm{C}$ for $10 \mathrm{~min}$. The supernatant was transferred into fresh tube. The sample protein concentration was measured with Pierce Coomassie Plus (Bradford) Assay Kit (23236, ThermoFisher) and adjusted to $1 \mu \mathrm{g} / \mu \mathrm{L}$. $20 \mu \mathrm{L}$ of sample or SOD assay buffer (blanks) was added to 96-well assay plate, $160 \mu \mathrm{L}$ NBT/enzyme working solution was added into all wells, and $20 \mu \mathrm{L}$ of reaction initiation working solution was added to all wells except for Blank2. The plate was incubated at $37^{\circ} \mathrm{C}$ for $30 \mathrm{~min}$ before being read at $560 \mathrm{~nm}$ on a microplate reader (BioTek). The SOD activity was calculated as follows:

$$
\% \text { inhibition }=\frac{(\text { Ablank } 1-\text { Asample })}{(\text { Ablank } 1-\text { Ablank } 2)} * 100 .
$$

SOD enzyme activity in the sample $=\%$ inhibition $/(1-$ $\%$ inhibition).
2.9. Quantitative Real-Time PCR. The total RNA from HUVECs treated with oxLDL and/or PD for $24 \mathrm{hrs}$ was extracted with Trizol reagent (ET111-01, TransGen Biotech, Beijing, China). The first-strand cDNA was synthesized using an M-MLV Reverse Transcriptase kit (Invitrogen, Carlsbad, CA) and was diluted 10-fold with RNase free $\mathrm{ddH}_{2} \mathrm{O}$ before use. Real-time quantitative RT-PCR was executed with an SYBR Premix Ex TaqTM kit (Takara, Dalian, China) in a $20 \mu \mathrm{L}$ reaction volume on a ABI Step One (Applied Biosystems, Foster City, CA) with the following cycling program: $95^{\circ} \mathrm{C}$ for $2 \mathrm{~min}$ followed by 40 cycles of $95^{\circ} \mathrm{C}$ for $15 \mathrm{sec}, 58^{\circ} \mathrm{C}$ for $30 \mathrm{sec}$, and $68^{\circ} \mathrm{C}$ for $30 \mathrm{sec}$. The relative mRNA level was calculated using the $2^{-\Delta \Delta \mathrm{Ct}}$ method with GAPDH as the internal control. The primers were listed in Table 1.

2.10. Western Blot. The HUVECs were lyzed in $100 \mu \mathrm{L}$ of RIPA buffer (50 mM Tris-cl pH 7.4, $150 \mathrm{mM} \mathrm{NaCl,} 1 \%$ NP40, and $0.25 \%$ Na-deoxycholate) containing $1 \mathrm{x}$ complete protease inhibitor cocktail (Roche Diagnostics, Indianapolis, IN) and 1x phosphatase inhibitor cocktail (Sigma, St. Louis, 


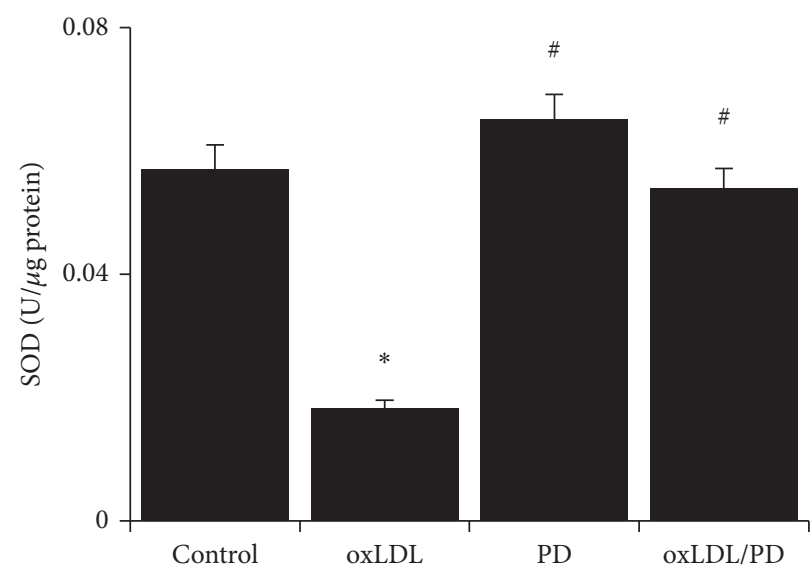

FIGURE 3: Pinoresinol diglucoside relieves the inhibition of SOD activity by oxLDL. The total SOD enzymatic activity of HUVECs treated with $40 \mu \mathrm{g} / \mathrm{mL}$ oxLDL and/or $1 \mu \mathrm{mol} / \mathrm{L}$ PD was analyzed using a commercially available assay kit. Experiments were performed 3 independent times with 3 replications. ${ }^{*} p<0.05$ compared to control cells; ${ }^{\#} p<0.05$ compared to oxLDL-treated cells.

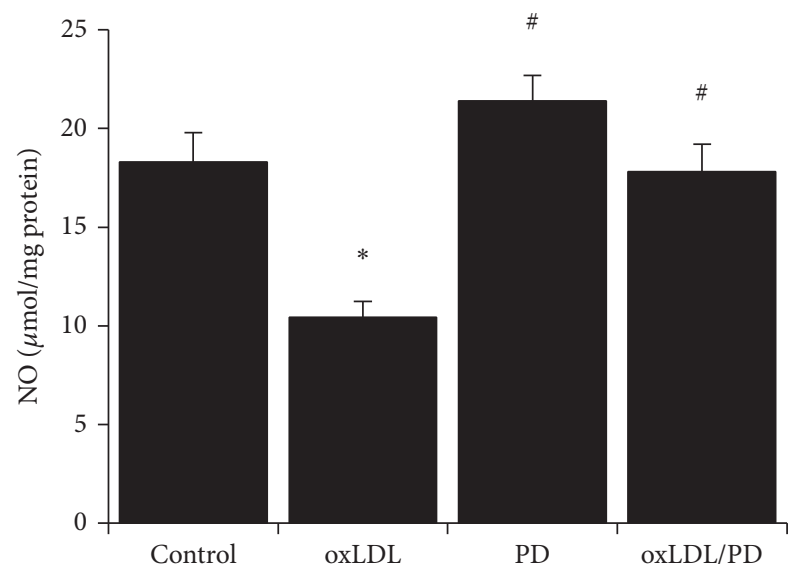

(a)

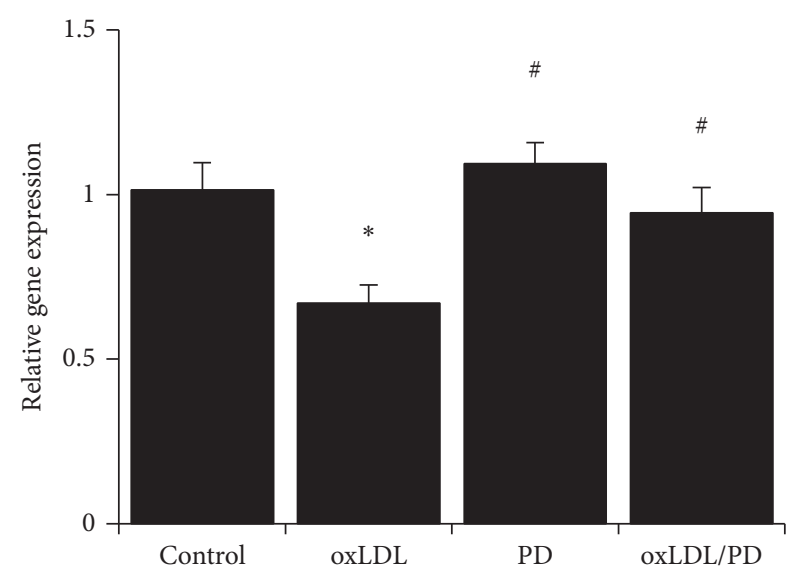

(b)

FIgURE 4: Pinoresinol diglucoside alleviates oxLDL-induced inhibition of NO production. (a) The total NO metabolites levels in HUVECs treated with $40 \mu \mathrm{g} / \mathrm{mL}$ oxLDL and/or $1 \mu \mathrm{mol} / \mathrm{L}$ PD were measured using a commercial assay kit. (b) The mRNA levels of eNOS in HUVECs treated with $40 \mu \mathrm{g} / \mathrm{mL}$ oxLDL and/or $1 \mu \mathrm{mol} / \mathrm{L}$ PD were assessed by quantitative real-time PCR. Experiments were performed 3 independent times with 3 replications. ${ }^{*} p<0.05$ compared to control cells; ${ }^{*} p<0.05$ compared to oxLDL-treated cells.

TABLE 1: PCR primer sequence.

\begin{tabular}{lc}
\hline Primer & Sequence \\
\hline GAPDH_F & CCACTAGGCGCTCACTGTTC \\
GAPDH_R & AGGCGCCCAATACGACCAA \\
hNF-kB_F & GCAGATGGCCCATACCTTCA \\
hNF-kB_R & TAGAGGCACCAGGTAGTCCA \\
hICAM1_F & CCCCTCAAAAGTCATCCTGC \\
hICAM1_R & GGGTCTCTATGCCCAACAACT \\
hLox-1-F & CTGACCTCCTAACACAAG \\
hLox-1-R & TGAAGTCCAGATCAGCTC \\
heNOS-F & GATGAGTATGACGTGGTGTCCC \\
heNOS-R & CCGAGGGGAGCTGTTGTA \\
\hline
\end{tabular}

MO) on ice for $30 \mathrm{~min}$. After centrifugation at $10000 \times \mathrm{g}$ at $4^{\circ} \mathrm{C}$ for $15 \mathrm{~min}$, the supernatant was collected and protein concentration was measured with Pierce Coomassie Plus (Bradford) Assay Kit (23236, ThermoFisher). $30 \mu \mathrm{g}$ total protein was resolved in a $8 \%$ sodium dodecyl sulfate polyacrylamide gel and transferred onto a PVDF membrane, which was blocked in 5\% nonfat milk in PBST $(0.1 \%$ Tween 20 in PBS) at room temperature for $30 \mathrm{~min}$ followed by being incubated with specified first antibodies at $4^{\circ} \mathrm{C}$ overnight. Next day, the membranes were washed 3 times at $5 \mathrm{~min}$ each time with PBST and then incubated with proper horseradish peroxidase-conjugated secondary antibodies (Jackson ImmunoResearch, West Grove, PA) for $60 \mathrm{~min}$ at room temperature. The specific bands were detected with Pierce ECL Plus Substrate (ThermoFisher). The primary antibodies used were p-NF- $\kappa$ B p65 (ab86299), NF$\kappa$ B p65 (ab16502), ICAM-1 (ab124759), and LOX-1 (ab60178) from Abcam (Cambridge, MA), p-p38MAPK (4511), and 


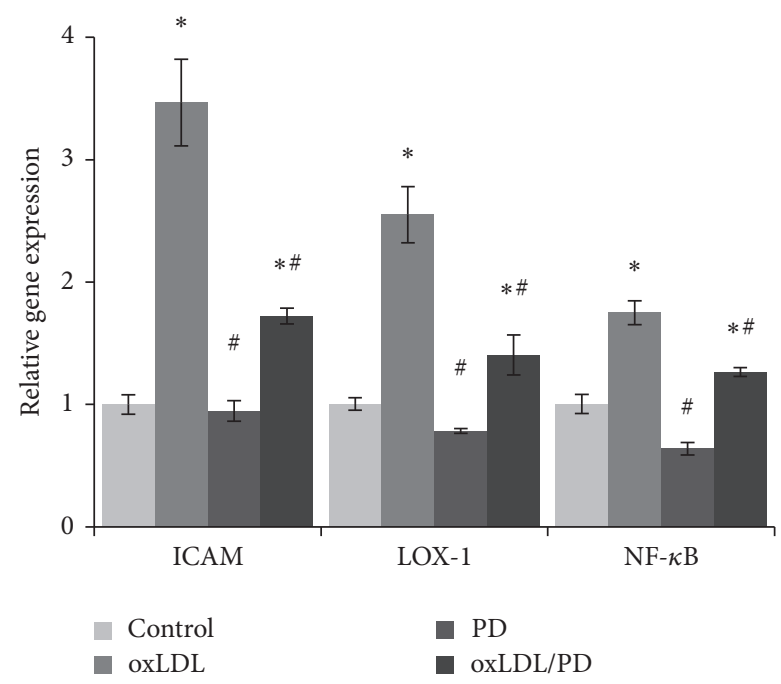

(a)

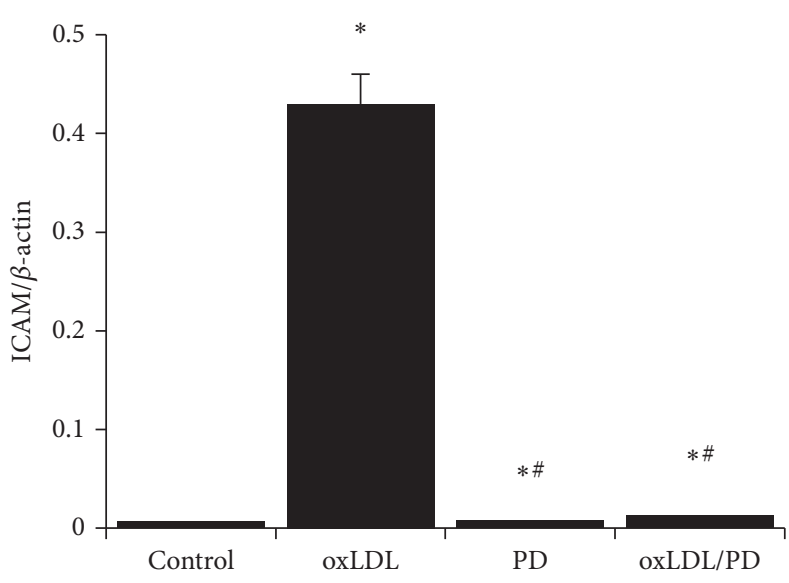

(c)

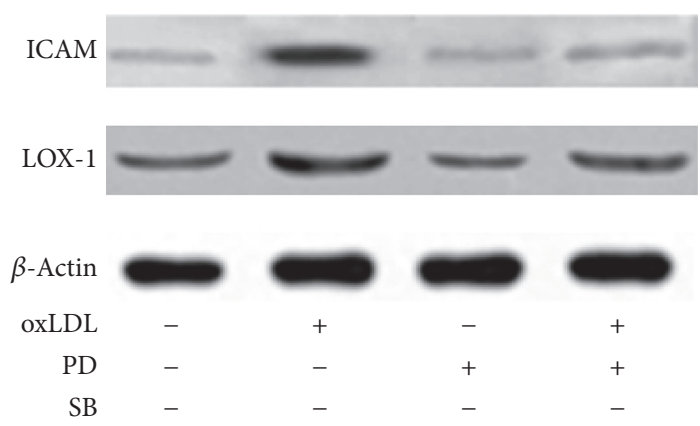

(b)

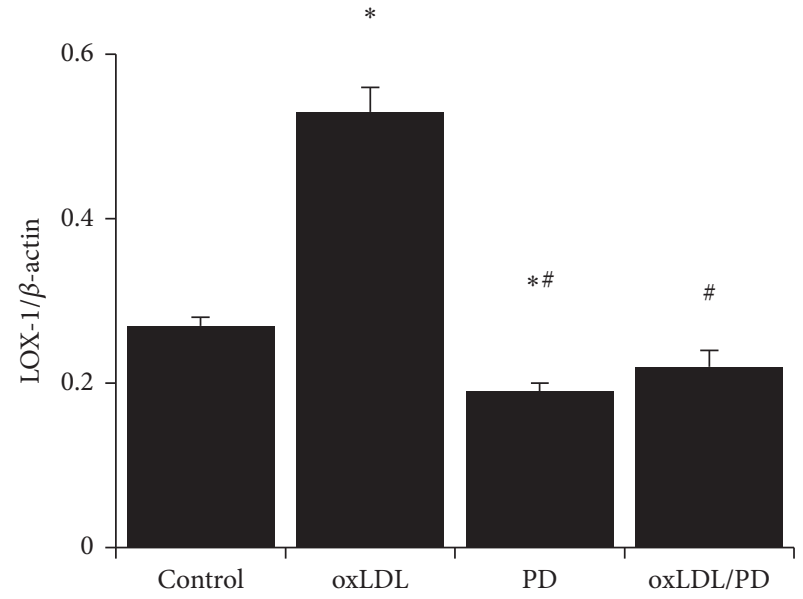

(d)

FIgURE 5: Pinoresinol diglucoside inhibits oxLDL-induced increase of LOX-1, ICAM, and NF- $\kappa$ B expression. (a) The mRNA levels of LOX-1, ICAM1, and NF- $\kappa$ B were analyzed using quantitative real-time PCR. (b) The protein levels of LOX-1 and ICAM were evaluated by western blot. The results of quantitative analysis of ICAM (c) and LOX-1 (d) western blot were shown. Experiments were performed 3 independent times with 3 replications. ${ }^{*} p<0.05$ compared to control cells; ${ }^{*} p<0.05$ compared to oxLDL-treated cells.

p38MAPK (8690) from Cell Signaling (Shanghai, China) and $\beta$-actin (TA-09) from ZSGB-Bio (Beijing, China).

2.11. Statistical Analysis. All experiments were performed in triplicate independently for at least three times. The data was presented as mean \pm SEM. The differences between groups were analyzed using one-way analysis of variance or Student's $t$-test. It was considered statistically significant if $p<0.05$.

\section{Results}

3.1. Pinoresinol Diglucoside Inhibits oxLDL-Induced Endothelial Apoptosis. Treatment of $100 \mu \mathrm{g}$ oxLDL for $24 \mathrm{hrs}$ caused 25.7\% HUVECs undergoing apoptosis, which was significantly higher than that of control cells (1.2\%) (Figure 1).
Pretreating cells with $0.1 \mu \mathrm{mol} / \mathrm{L}$ of $\mathrm{PD}$ reduced the apoptotic cells to $17.2 \%$ whereas $1 \mu \mathrm{mol} / \mathrm{L}$ of $\mathrm{PD}$ abrogated the apoptosis-inducing effect of oxLDL (Figure 1). Therefore, the $1 \mu \mathrm{mol} / \mathrm{L}$ dose of PD was used in ensuing experiments.

\subsection{Pinoresinol Diglucoside Alleviates Oxidative Stress Caused} by oxLDL. The ROS levels in HUVECs were assessed using DCFH-DA staining followed by flow cytometry or fluorescence microscopy. The production of ROS in HUVECs treated with oxLDL was markedly increased compared to control cells (Figures 2(a) and 2(b)). The presence of PD reduced the ROS level by more than $20 \%$ in oxLDL-treated HUVECs (Figures 2(a) and 2(b)). Meanwhile, the level of lipid peroxidation (MDA content) increased more than $70 \%$ by oxLDL treatment and about $80 \%$ of the increased MDA level was inhibited by PD (Figure 2(c)). 


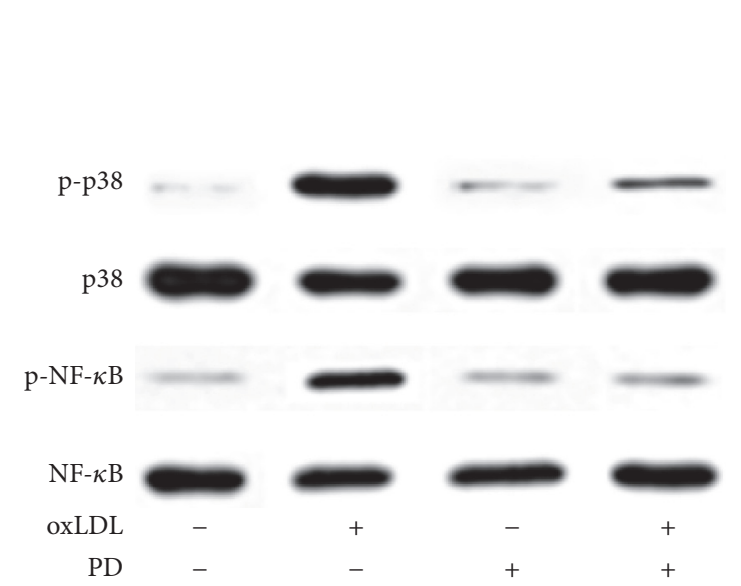

(a)

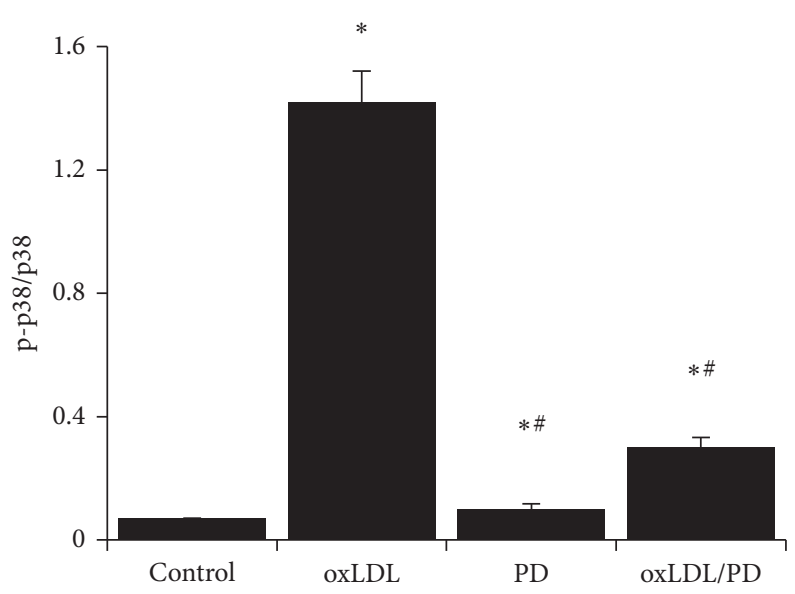

(b)

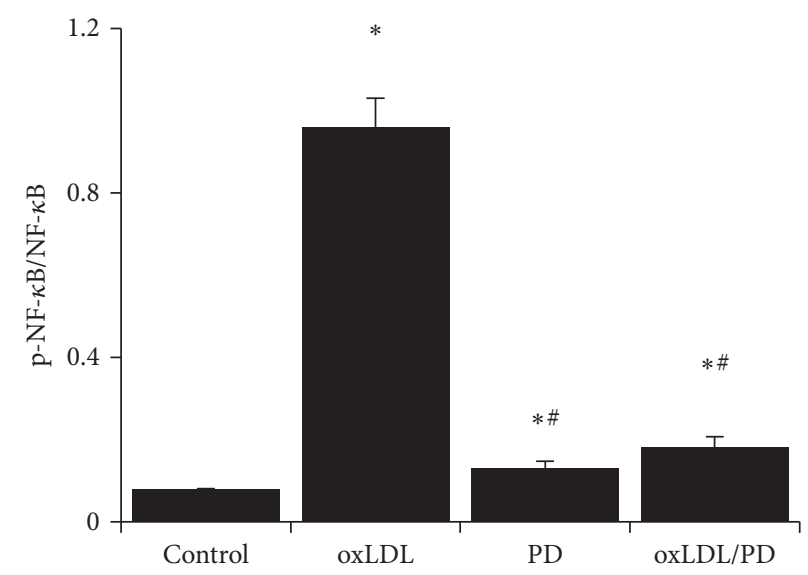

(c)

FIGURE 6: The oxLDL promoted activation of p38MAPK/NF- $\kappa$ B signaling is inhibited by pinoresinol diglucoside. (a) HUVECs were treated with or without $1 \mu \mathrm{mol} / \mathrm{L}$ of PD for $60 \mathrm{~min}$ before being treated with $40 \mathrm{mg} / \mathrm{mL}$ of oxLDL for $45 \mathrm{~min}$. The levels of p-p38MAPK, p38MAPK, p-NF- $\kappa$ B p 65 , and NF- $\kappa$ B p 65 were analyzed by western blot. The ratio of p-p38MAPK/p38MAPK (b) and p-NF- $\kappa$ B p65/NF- $\kappa$ B p65 (c) was shown. Experiments were performed 3 independent times with 3 replications. ${ }^{*} p<0.05$ compared to control cells; ${ }^{\#} p<0.05$ compared to oxLDL-treated cells.

3.3. Pinoresinol Diglucoside Reverses the oxLDL-Induced Reduction of SOD Activities. The total SOD activities of oxLDL-treated HUVECs were reduced about 68\% compared to control cells (Figure 3). Pretreating HUVECs with pinoresinol diglucoside abrogated the inhibition of SOD activities by oxLDL (Figure 3).

3.4. Pinoresinol Diglucoside Alleviates oxLDL-Induced Inhibition of NO Production in HUVECs. The HUVECs treated with oxLDL produced more than $40 \%$ less NO compared to untreated cells (Figure 4(a)). This decreased production of NO in oxLDL-treated HUVECs was fully inhibited by pinoresinol diglucoside (Figure 4(a)). Correspondingly, oxLDL-caused over $30 \%$ reduction of the expression of eNOS compared to untreated HUVECs (Figure 4(b)). Pretreatment of HUVECs with PD completely abolished the inhibition of eNOS expression by oxLDL (Figure 4(b)).
3.5. Pinoresinol Diglucoside Inhibits the Expression of Genes Involved in Inflammation, Adhesion, and oxLDL Uptake. The mRNA (Figure 5(a)) and protein (Figures 5(b)-5(d)) levels of lectin-like oxidized low-density lipoprotein receptor-1 (Lox1), intercellular adhesion molecule 1 (CAM1), and nuclear factor of kappa light polypeptide gene enhancer in B-cells $1(\mathrm{NF}-\kappa \mathrm{B})$ in HUVECs were upregulated 1.7- to 3.5-fold by oxLDL, and such upregulation was essentially abrogated by pinoresinol diglucoside.

3.6. The oxLDL Promoted Activation of p38MAPK/NF- $\kappa B$ Signaling Is Inhibited by Pinoresinol Diglucoside. Treating HUVECs with oxLDL-induced strong phosphorylation of p38MAPK and NF- $\kappa$ B p65 (Figure 6). Pinoresinol diglucoside alone did not have obvious effects on p38MAPK or NF- $\kappa$ B p65 phosphorylation but it significantly inhibited oxLDL-induced phosphorylation of p38MAPK and NF- $\kappa \mathrm{B}$ p65 (Figure 6). 


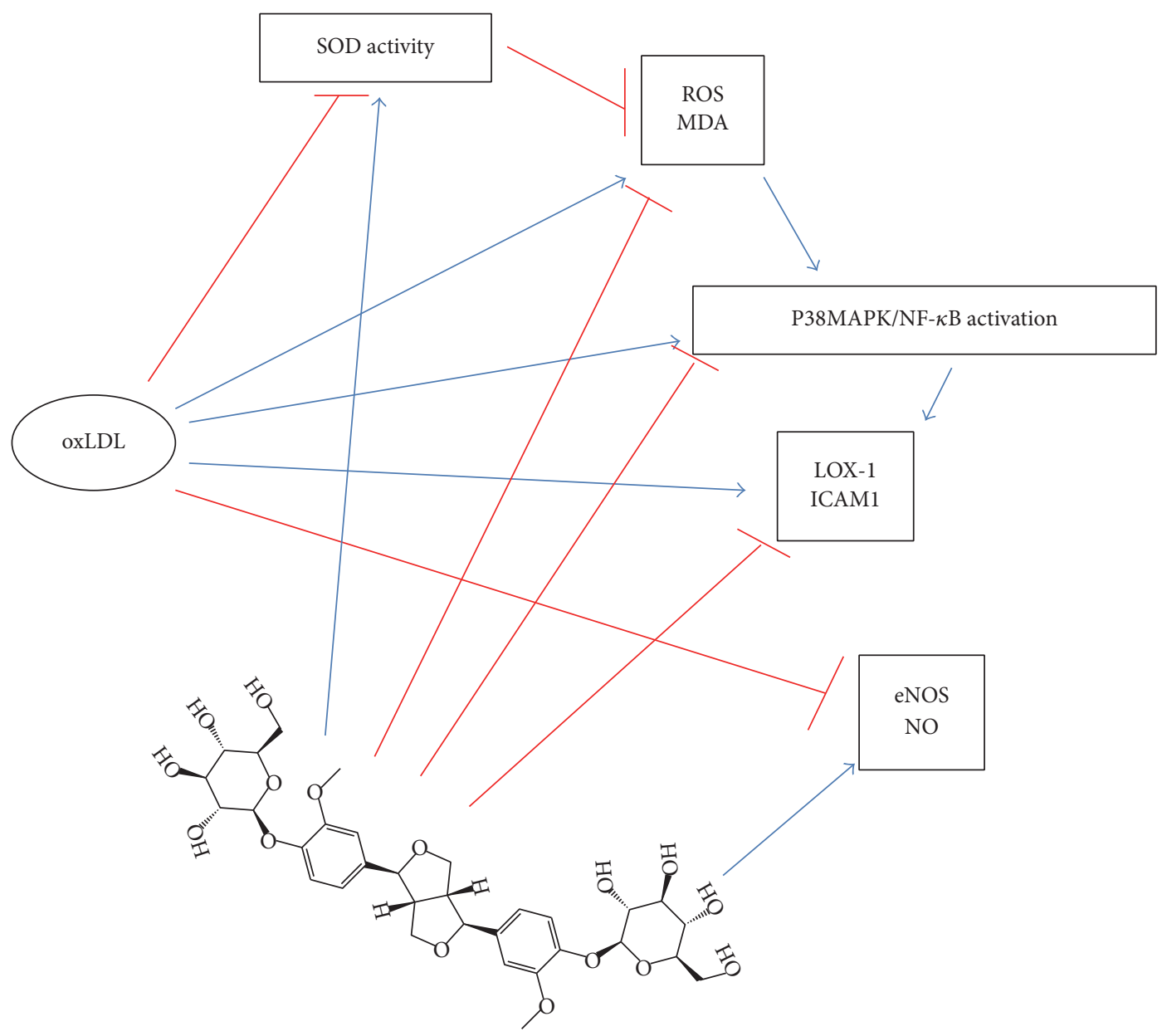

FIGURE 7: The proposed working model for pinoresinol diglucoside protecting HUVECs against oxLDL-induced injuries. Refer to test for details.

\section{Discussion}

Pinoresinol diglucoside, a natural flavanone found in licorice, showed the ability to protect endothelial cells from oxLDLinduced damages. Specifically, pinoresinol diglucoside alleviated cellular oxidative stress and endothelial apoptosis caused by oxLDL, reversed the inhibition of NO production by oxLDL, and inhibited oxLDL-induced overexpression of genes involved in cell adhesion, inflammation, and oxLDL uptake. Moreover, pinoresinol diglucoside effectively inhibited the activation of $\mathrm{p} 38 \mathrm{MAPK}$ and NF- $\kappa \mathrm{B}$ by oxLDL.

Oxidized LDL has long been shown to cause the death of endothelial cells through excessive oxidative stress [21, $23,24]$, and the oxLDL-caused endothelial dysfunction could be intervened by targeting different aspects of oxLDL actions. Isothiocyanates sulforaphane, benzyl isothiocyanate, and phenethyl isocyanate promoted the expression of heme oxygenase-1 and glutamate cysteine ligase in a nuclear factor erythroid 2-related factor 2 (Nrf2) dependent manner, resulting in subdued ROS production and NF- $\kappa$ B activation in HUVECs upon oxLDL treatment [23]. Another study showed that thioredoxin inhibited oxLDL-induced expression of endothelial cell adhesion molecules (ICAM and VCAM) in HUVECs by promoting the phosphorylation, nuclear translocation, and nuclear retention of SMAD3 protein [25]. The expression of T-box 20 gene was shown to be suppressed by oxLDL in HUVECs or the arteries of mice fed with high-fat diet; and overexpressing T-box 20 reduced oxLDLinduced ROS production and expression of intercellular adhesion molecules in HUVECs through promoting peroxisome proliferator-activated receptors gamma expression [26]. These data demonstrated that the excessive ROS production and overexpression of cell adhesion molecules were the main theme of oxLDL-induced endothelial dysfunction.

Additionally, oxLDL has been shown to induce the expression and the dissociation from microtubules of endothelial arginase II as well as its translocation from mitochondria into cytoplasm to reduce the levels of endothelial nitric oxide, resulting in the impairment of NO signaling and related endothelial function [27, 28]. The activation of arginase II by oxLDL was through a LOX-1 dependent RhoA/ROCK pathway [29], which was consistent with the observation that arginase II was dissociated from microtubules by oxLDL [28]. Phosphocreatine antagonized the apoptotic effect of oxLDL by activating PI3K/Akt/eNOS pathway and $\mathrm{NO}$ production in 
HUVECs [30]. Meanwhile, p38MAPK/NF- $\kappa$ B pathway has been shown to be strongly activated by oxLDL and served as an effective target for intervention [31, 32]. Moreover, puerarin protected against oxLDL-caused endothelial injury by inhibiting oxLDL-induced LOX-1 overexpression, p38MAPK activation, and eNOS inhibition [32]. Our data demonstrated that pinoresinol diglucoside exerted multifaceted effects in protecting HUVECs against oxLDL-induced endothelial dysfunction (Figure 7). PD blocked the activation of p38MAPK/NF- $\kappa$ B and LOX-1 signaling to diminish the acute effects of oxLDL and would prevent endothelial adhesion of inflammatory cells. PD stimulated NO production and chronically inhibition of ROS production induced by oxLDL would maintain proper endothelial functions.

\section{Conclusion}

PD inhibited oxLDL-induced upregulation of LOX-1 and ICAM-1, ROS production, lipid peroxidation, and p38MAPK/NF- $\kappa$ B activation. Meanwhile, PD also relieved the inhibition of SOD activity, NO production, and eNOS expression by oxLDL in HUVECs, indicating that PD was effective in protecting endothelial cells from oxLDL-caused injuries and warranting further studies on its potential clinical benefits in treating cardiovascular diseases.

\section{Competing Interests}

All authors declare that they have no conflict of interests.

\section{Authors' Contributions}

Jinpeng Yao and Zhipeng Zou contributed equally to this study.

\section{References}

[1] "Global, regional, and national age-sex specific all-cause and cause-specific mortality for 240 causes of death, 1990-2013: a systematic analysis for the Global Burden of Disease Study 2013," The Lancet, vol. 385, no. 9963, pp. 117-171, 2015.

[2] A. E. Moran, G. A. Roth, J. Narula, and G. A. Mensah, "19902010 Global cardiovascular disease atlas," Global Heart, vol. 9, no. 1, pp. 3-16, 2014.

[3] I. Kriszbacher, M. Koppan, and J. Bodis, "Inflammation, atherosclerosis, and coronary artery disease," The New England Journal of Medicine, vol. 353, no. 4, pp. 429-430, 2005.

[4] A. J. Lusis, "Atherosclerosis," Nature, vol. 407, no. 6801, pp. $233-$ 241, 2000.

[5] R. Ross, "Atherosclerosis-an inflammatory disease," The New England Journal of Medicine, vol. 340, no. 2, pp. 115-126, 1999.

[6] C.-S. Huang, A.-H. Lin, T.-C. Yang, K.-L. Liu, H.-W. Chen, and C.-K. Lii, "Shikonin inhibits oxidized LDL-induced monocyte adhesion by suppressing NFkB activation via up-regulation of PI3K/Akt/Nrf2-dependent antioxidation in EA.hy926 endothelial cells," Biochemical Pharmacology, vol. 93, no. 3, pp. 352-361, 2015.
[7] K. M. Botham and C. P. D. Wheeler-Jones, "Postprandial lipoproteins and the molecular regulation of vascular homeostasis," Progress in Lipid Research, vol. 52, no. 4, pp. 446-464, 2013.

[8] P. Gao, X.-M. Wang, D.-H. Qian et al., "Induction of oxidative stress by oxidized LDL via meprin $\alpha$-activated epidermal growth factor receptor in macrophages," Cardiovascular Research, vol. 97, no. 3, pp. 533-543, 2013.

[9] C. H. Hung, S. H. Chan, P. M. Chu, H. C. Lin, and K. L. Tsai, "Metformin regulates oxLDL-facilitated endothelial dysfunction by modulation of SIRT1 through repressing LOX1-modulated oxidative signaling," Oncotarget, vol. 7, no. 10, pp. 10773-10787, 2016.

[10] K.-L. Tsai, L.-H. Chen, S.-H. Chiou et al., "Coenzyme Q10 suppresses oxLDL-induced endothelial oxidative injuries by the modulation of LOX-1-mediated ROS generation via the AMPK/PKC/NADPH oxidase signaling pathway," Molecular Nutrition and Food Research, vol. 55, no. 2, pp. S227-S240, 2011.

[11] I. M. Fearon, "OxLDL enhances L-type $\mathrm{Ca}^{2+}$ currents via lysophosphatidylcholine-induced mitochondrial reactive oxygen species (ROS) production," Cardiovascular Research, vol. 69, no. 4, pp. 855-864, 2006.

[12] E. Liu, L. Han, J. Wang et al., "Eucommia ulmoides bark protects against renal injury in cadmium-challenged rats," Journal of Medicinal Food, vol. 15, no. 3, pp. 307-314, 2012.

[13] S. A. Park, M.-S. Choi, U. J. Jung et al., "Eucommia ulmoides oliver leaf extract increases endogenous antioxidant activity in type 2 diabetic mice," Journal of Medicinal Food, vol. 9, no. 4, pp. 474-479, 2006.

[14] M.-K. Lee, M.-J. Kim, S.-Y. Cho et al., "Hypoglycemic effect of Du-zhong (Eucommia ulmoides Oliv.) leaves in streptozotocininduced diabetic rats," Diabetes Research and Clinical Practice, vol. 67, no. 1, pp. 22-28, 2005.

[15] S. A. Park, M.-S. Choi, M.-J. Kim et al., "Hypoglycemic and hypolipidemic action of Du-zhong (Eucommia ulmoides Oliver) leaves water extract in C57BL/KsJ- $d b / d b$ mice," Journal of Ethnopharmacology, vol. 107, no. 3, pp. 412-417, 2006.

[16] X. Jin, Y. Otonashi-Satoh, P. Sun et al., "Endotheliumderived hyperpolarizing factor (EDHF) mediates endotheliumdependent vasodilator effects of aqueous extracts from eucommia ulmoides oliv. leaves in rat mesenteric resistance arteries," Acta Medica Okayama, vol. 62, no. 5, article 6, pp. 315-325, 2008.

[17] L.-F. Luo, W.-H. Wu, Y.-J. Zhou, J. Yan, G.-P. Yang, and D.S. Ouyang, "Antihypertensive effect of Eucommia ulmoides Oliv. extracts in spontaneously hypertensive rats," Journal of Ethnopharmacology, vol. 129, no. 2, pp. 238-243, 2010.

[18] L. Li, J. Yan, K. Hu et al., "Protective effects of Eucommia lignans against hypertensive renal injury by inhibiting expression of aldose reductase," Journal of Ethnopharmacology, vol. 139, no. 2, pp. 454-461, 2012.

[19] X. Jing, W.-H. Huang, Y.-J. Tang et al., “Eucommia ulmoides Oliv. (Du-Zhong) lignans inhibit angiotensin II-stimulated proliferation by affecting P21, P27, and Bax expression in rat mesangial cells," Evidence-Based Complementary and Alternative Medicine, vol. 2015, Article ID 987973, 8 pages, 2015.

[20] Z.-Y. Li, X.-L. Deng, W.-H. Huang et al., "Lignans from the bark of Eucommia ulmoides inhibited Ang II-stimulated extracellular matrix biosynthesis in mesangial cells," Chinese Medicine, vol. 9, no. 1, article 8, 2014.

[21] C. Claise, M. Edeas, N. Chaouchi et al., "Oxidized-LDL induce apoptosis in HUVEC but not in the endothelial cell line EA.hy 926," Atherosclerosis, vol. 147, no. 1, pp. 95-104, 1999. 
[22] C. G. Fraga, B. E. Leibovitz, and A. L. Tappel, "Lipid peroxidation measured as thiobarbituric acid-reactive substances in tissue slices: characterization and comparison with homogenates and microsomes," Free Radical Biology and Medicine, vol. 4, no. 3, pp. 155-161, 1988.

[23] C.-S. Huang, A.-H. Lin, C.-T. Liu et al., "Isothiocyanates protect against oxidized LDL-induced endothelial dysfunction by upregulating Nrf2-dependent antioxidation and suppressing NF $\kappa$ B activation," Molecular Nutrition and Food Research, vol. 57, no. 11, pp. 1918-1930, 2013.

[24] J. P. Thomas, P. G. Geiger, and A. W. Girotti, "Lethal damage to endothelial cells by oxidized low density lipoprotein: role of selenoperoxidases in cytoprotection against lipid hydroperoxide- and iron-mediated reactions," Journal of Lipid Research, vol. 34, no. 3, pp. 479-490, 1993.

[25] B. Chen, W. Wang, T. Shen, and R. Qi, “Thioredoxin1 downregulates oxidized low-density lipoprotein-induced adhesion molecule expression via Smad3 protein," PLoS ONE, vol. 8, no. 9, Article ID e76226, 2013.

[26] T. Shen, Y. Zhu, J. Patel et al., “T-box20 suppresses oxidized low-density lipoprotein-induced human vascular endothelial cell injury by upregulation of PPAR- $\gamma$," Cellular Physiology and Biochemistry, vol. 32, no. 5, pp. 1137-1150, 2013.

[27] D. Pandey, A. Bhunia, Y. J. Oh et al., "OxLDL triggers retrograde translocation of arginase 2 in aortic endothelial cells via ROCK and mitochondrial processing peptidase," Circulation Research, vol. 115, no. 4, pp. 450-459, 2014.

[28] S. Ryoo, C. A. Lemmon, K. G. Soucy et al., "Oxidized lowdensity lipoprotein-dependent endothelial arginase II activation contributes to impaired nitric oxide signaling," Circulation Research, vol. 99, no. 9, pp. 951-960, 2006.

[29] S. Ryoo, A. Bhunia, F. Chang, A. Shoukas, D. E. Berkowitz, and L. H. Romer, "OxLDL-dependent activation of arginase II is dependent on the LOX-1 receptor and downstream RhoA signaling," Atherosclerosis, vol. 214, no. 2, pp. 279-287, 2011.

[30] A. Ahsan, G. Han, J. Pan et al., "Phosphocreatine protects endothelial cells from oxidized low-density lipoproteininduced apoptosis by modulating the PI3K/Akt/eNOS pathway," Apoptosis, vol. 20, no. 12, pp. 1563-1576, 2015.

[31] M.-H. Bao, Y.-W. Zhang, X.-Y. Lou, Y. Cheng, and H.-H. Zhou, "Protective effects of Let-7a and Let-7b on oxidized low-density lipoprotein induced endothelial cell injuries," PLoS ONE, vol. 9, no. 9, Article ID e106540, 2014.

[32] M.-H. Bao, Y.-W. Zhang, X.-Y. Lou, Y. Xiao, Y. Cheng, and H.-H. Zhou, "Puerarin protects endothelial cells from oxidized low density lipoprotein induced injuries via the suppression of LOX-1 and induction of eNOS," Canadian Journal of Physiology and Pharmacology, vol. 92, no. 4, pp. 299-306, 2014. 


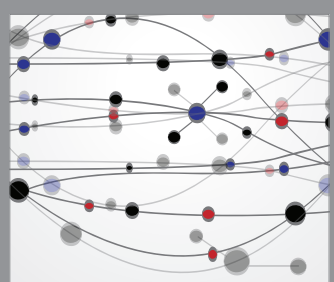

The Scientific World Journal
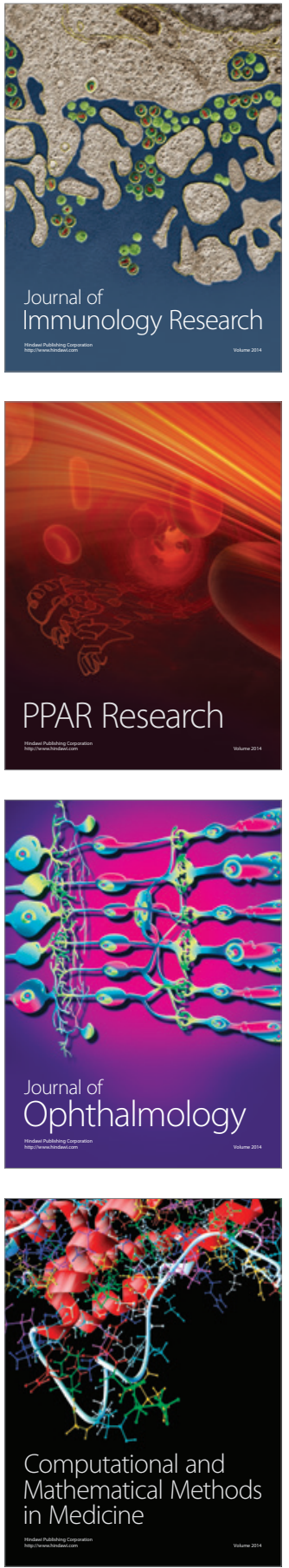

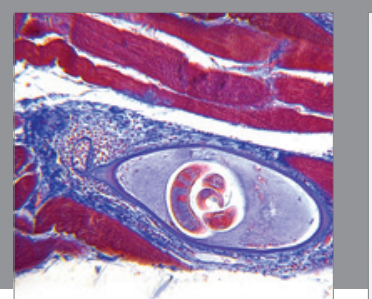

Gastroenterology Research and Practice

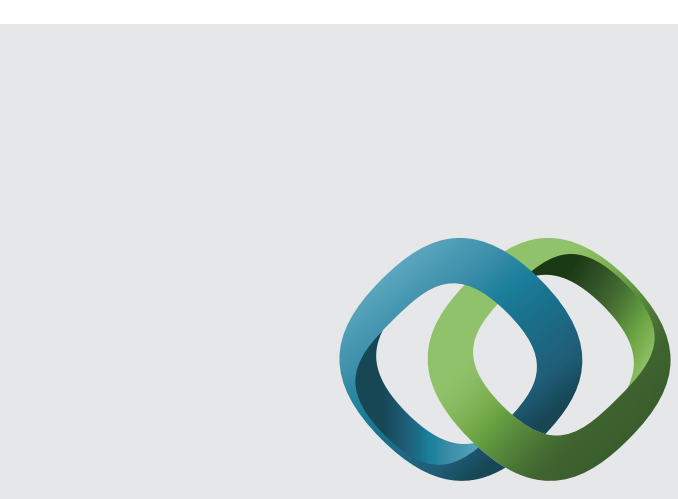

\section{Hindawi}

Submit your manuscripts at

http://www.hindawi.com
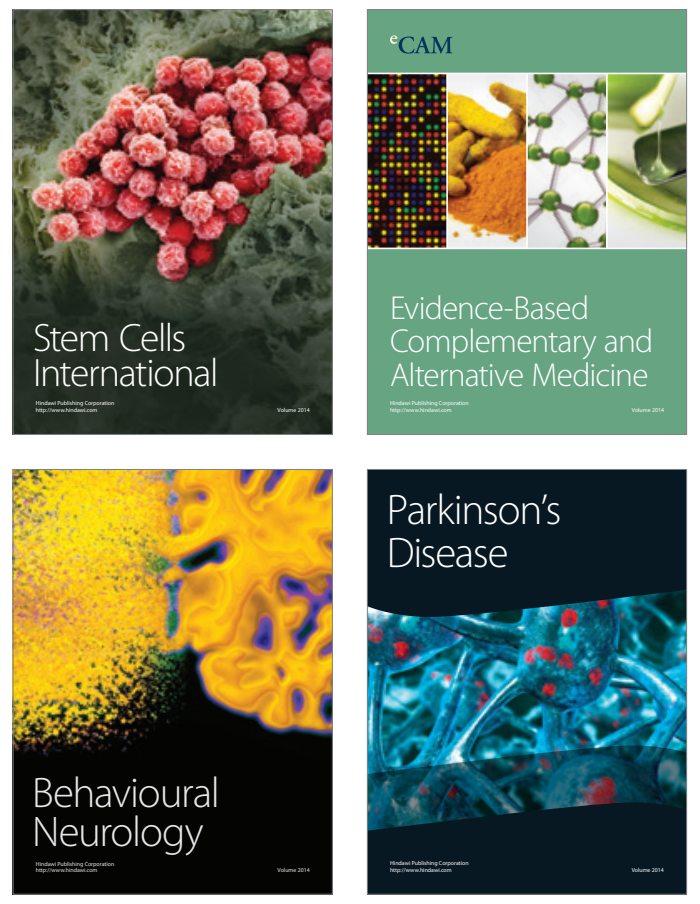
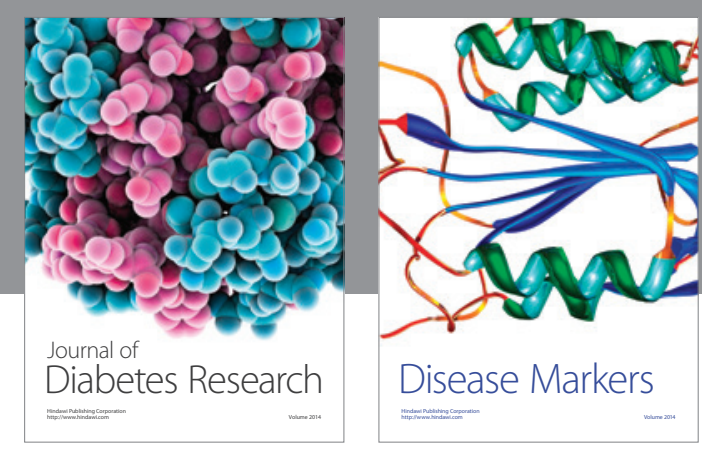

Disease Markers
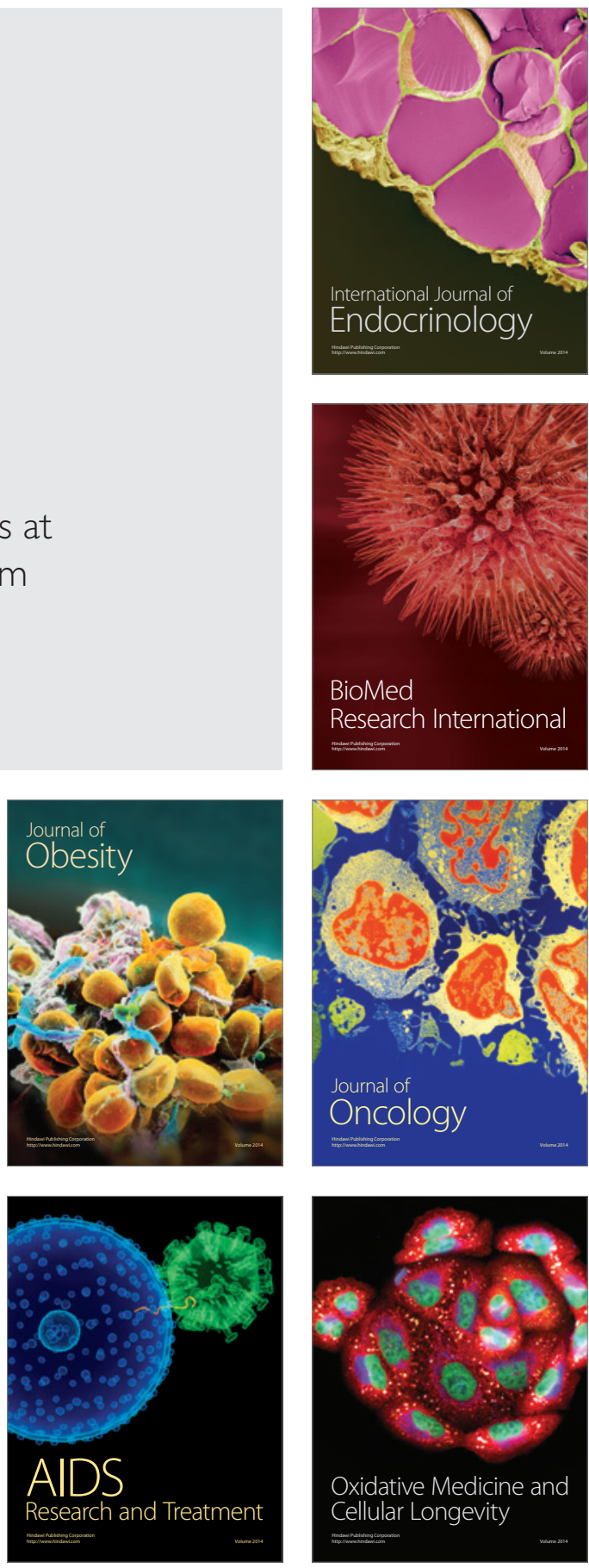